\title{
CYP2D6 Gene
}

National Cancer Institute

\section{Source}

National Cancer Institute. CYP2D6 Gene. NCI Thesaurus. Code C26517.

This gene plays a role in the metabolism of numerous clinically-relevant drugs. It is also involved in the oxidation of xenobiotics. 